\title{
Suprabenthic gradients of swimming activity by cold-water gammaridean amphipod Crustacea over a muddy shelf in the Gulf of Saint Lawrence*
}

\author{
Bernard Sainte-Marie ** \& Pierre Brunel ${ }^{* * *}$ \\ Département de sciences biologiques, Universíté de Montréal, Montréal, Québec H3C 3J7, Canada
}

\begin{abstract}
From May to October 1961-62 and 1969, suprabenthic sampling above homologous, uniformly deep $(119 \mathrm{~m})$, cold $\left(\vec{x}=0.8^{\circ} \mathrm{C}\right)$, and muddy grounds of Baie des Chaleurs, Gulf of Saint Lawrence, yielded 82 gammaridean amphipod species belonging to 27 families. Fifty-one species regarded as suprabenthic are grouped into 7 categories according to amplitude, intensity and regularity of their swimming behavior. The 14 Oedicerotidae account for $88 \%$ of suprabenthic amphipods, whereas in the endobenthos the lysianassid Paratryphosites abyssi is dominant (53\%), the Oedicerotidae $(3.3 \%)$ being only the sixth most important family. True suprabenthic species typically swim to at least $3.7 \mathrm{~m}$ above the bottom. Permanent members of the suprabenthos, including large predatory species, a carrion feeder, and many detritivores, are thought to forage in the suprabenthic layer.
\end{abstract}

\section{INTRODUCTION}

The existence of daily or seasonal swimming activity in various benthic taxa is well established (e.g. Tattersall 1913, Fage 1933, Bossanyi 1957, Jansson \& Kallander 1968, Hesthagen 1973, Porter \& Porter 1977, Brunel 1979, Sainte-Marie \& Brunel 1983). Suprabenthos often designated hyperbenthos, meroplankton, demersal zooplankton, benthopelagic plankton or even epibenthos - includes all bottom-dependent animals which perform, with varying regularity, daily or seasonal vertical migrations above the bottom (Brunel et al. 1978). Mysids, amphipods, cumaceans, isopods and polychaetes are frequent and abundant components of the suprabenthos. In cold-water environments, amphipods are often the dominant suprabenthic taxon (Besner 1976, Brunel 1979).

Importance and persistence of this community are still open to discussion, and have been challenged by some researchers (Anger \& Valentin 1976, Robichaux et al. 1981). The suprabenthos and its interactions with

- Contribution to the program of GIROQ (Groupe interuniversitaire de Recherches océanographiques du Québec)

- Present address: Department of Biology, Dalhousie University, Halifax, Nova Scotia, B3H 4J1, Canada

-. Addressee for reprint requests demersal or pelagic fishes have become the focus of increasing attention (e.g. Brunel 1968, Thomas \& Jelley 1972, Hobson \& Chess 1976, Cornet et al. 1983), as a result of a growing interest in benthic-pelagic coupling. Investigation in this field has advanced slowly, because of the difficulty in obtaining quantitative suprabenthic samples not contaminated by non-swimming benthos (Brunel et al. 1978, Hesthagen \& Gjermundsen 1978, Huberdeau \& Brunel 1982) and the simultaneous benthic and pelagic samples which are necessary for proper comparisons. Parallel and independent progress has been made by workers in tropical, mostly coral-reef, and temperate to cold-water environments. There is unfortunately little or no mutual acknowledgement of their respective works. This isolation may in part be due to their different terminology: 'demersal zooplankton' or 'meroplankton' (somewhat inaccurate, in our view) is used by tropical researchers whereas 'suprabenthos' or 'hyperbenthos' is used in the north. Semantic agreement would certainly speed up progress.

Much previous work has been carried out in intertidal or shallow water environments less than 15 metres in depth. At greater shelf depths, little information is available (e.g. Hesthagen 1973, Hesthagen \& Gjermundsen 1979, Sorbe 1982, Sainte-Marie \& Brunel 1983). We describe here cold-water populations of 
gammaridean amphipods from the deep (119 metres) mud basin of Baie des Chaleurs in the Gulf of Saint Lawrence, using endobenthic (= infaunal), suprabenthic and planktonic data and cod stomach contents. Fifty-one species out of a total of 82 are common in the suprabenthos from May to October from the sediment surface to a few metres above. Using this major component of the suprabenthic community, our objectives were: Firstly, to evaluate the distinctness of that community and to quantify its differences from the underlying epi- and endobenthic community. Secondly, to obtain some insight into the factors responsible for near-bottom swimming and vertical migrations; we have therefore compared the structure of populations in Baie des Chaleurs with that of two adjacent but different ecosystems, in the Lower St. Lawrence Estuary (Besner 1976) and Saguenay Fjord (Brunel et al. 1980). Thirdly, to fill the numerous gaps in our knowledge of the autecology of gammaridean amphipods (Enequist 1949, Barnard 1969, Bousfield 1973, Besner 1976), since their different regimes of swimming activity readily provide a solid explanatory basis for their ecological and taxonomic diversity and for their evolutionary history. Data on daily and seasonal variations of density will be presented elsewhere (SainteMarie \& Brunel in prep.).

\section{MATERIAL AND METHODS}

Data were collected from 2 neighboring shelf stations located $3.5 \mathrm{~km}$ apart in Baie des Chaleurs, Gulf of Saint Lawrence (Station $112 \mathrm{M}$ : $48^{\circ} 18^{\prime} 07^{\prime \prime} \mathrm{N}$, $64^{\circ} 21^{\prime} 22^{\prime \prime} \mathrm{W}$; Station $112 \mathrm{~N}$ : $48^{\circ} 17^{\prime} 15^{\prime \prime} \mathrm{N}, 64^{\circ} 19^{\prime} 00^{\prime \prime} \mathrm{W}$; Fig. 1). Both stations are on a broad, $119 \mathrm{~m}$ deep, uniformly muddy and cold $\left(0.4\right.$ to $\left.1.6^{\circ} \mathrm{C}, \overline{\mathrm{x}}=0.8^{\circ} \mathrm{C}\right)$ plateau, the sediments of which are described by Schafer (1977) and Schafer \& Wagner (1978). At Stn $112 \mathrm{M}$, the mud contains $1 \%$ sand, $49 \%$ silt and $50 \%$ clay on the Wentworth scale. For our purposes, Stations

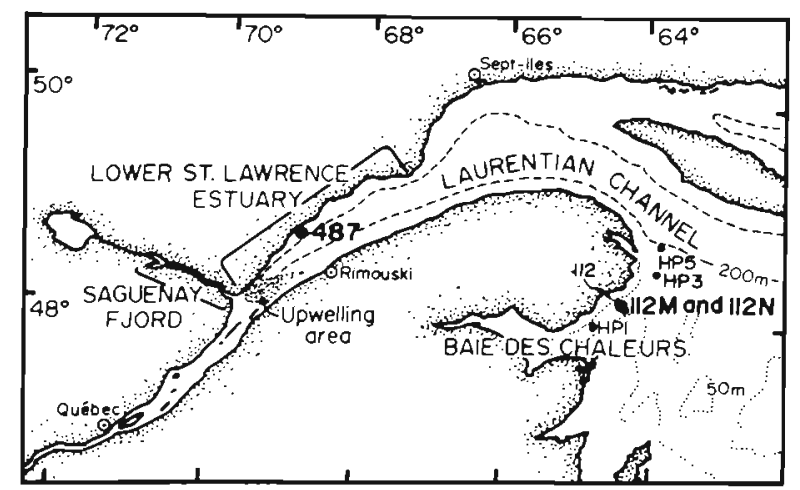

Fig. 1. Positions of major (larger lettering) and minor (smaller lettering) monitoring stations in the western Gulf of Saint Lawrence
$112 \mathrm{M}$ and $112 \mathrm{~N}$ may be considered as homologous. Ledoyer (1975) and Schafer \& Wagner (1978) show that the entire deep-mud basin of Baie des Chaleurs under arctic waters is inhabited by a common and characteristic fauna. Our own results confirm that the amphipod fauna is similar, both in species composition and proportions. Furthermore, the temporal pattern of suprabenthic swimming proved to be very similar in 1961-62 and in 1969 (Sainte-Marie \& Brunel in prep.).

Station $112 \mathrm{M}$ was sampled on a bimonthly day-andnight basis from May to October 1969 (22 samples), and on a hourly basis on 2-3 September 1969 (27 samples). Amphipods were collected there with the Macer-GIROQ suprabenthic sled, supporting paired, opening-and-closing $0.5 \mathrm{~mm}$ mesh standard plankton nets which quantitatively sample animals swimming exclusively at 28 to $64 \mathrm{~cm}$ and 106 to $142 \mathrm{~cm}$ above the bottom (Brunel et al. 1978, Huberdeau \& Brunel 1982). The 2 nets of the sled are referred to below as 'upper net' and 'lower net'.

At Station 112 N, 2 day-time and 2 night-time samples were taken twice a month from June to October 1961 and from May to July 1962. Sixty-one samples were thus obtained with a $3 \mathrm{~mm}$ mesh shrimp net $(48$ by $91 \mathrm{~cm}$ opening) mounted on the headline of a Yankee otter trawl, at 3.66 to $4.14 \mathrm{~m}$ above the bottom (Brunel 1972). This net is referred to below as 'shrimp net'. Without size measurements for all species, we have no way to account for the differences in sampling selectivity due to the larger meshes of the shrimp net.

An index $(\mathrm{K})$ of swimming activity above the bottom was computed for each species, following Brunel (1972) and Besner (1976), as the ratio Density in the upper net : Density in both nets, per tow of the MacerGIROQ pair of suprabenthic nets. Mean swimming activity $(\overline{\mathrm{K}})$ from May to October 1969 was then obtained by averaging all $\mathrm{K}$ values from that time series.

It was possible to identify accurately almost all species. Our confidence in the identity of our Metopa bruzelii is not high, and we were unable to distinguish species of young Paroediceros, which were therefore referred to $P$. propinquus, the adults of which considerably outnumbered those of $P$. Iynceus. Another young Oedicerotidae which was counted as a species could not be named with certainty.

\section{RESULTS}

\section{Family and species dominance and diversity}

The 41,640 amphipods caught in the 1969 seasonal sampling series belong to 77 species in 23 gammaridean families (Table 1). Only 5 uncommon species and 2 families are added to this list by the 23,972 
amphipods from the 24 h sampling of 2-3 September 1969. The combined list includes all species caught in the shrimp net in 1961-62 and also in the plankton, with the exception of Monoculodes edwardsi (Table 2). The full list will be published elsewhere.

Table 1 shows that the Oedicerotidae are overwhelmingly dominant in the suprabenthic samples, with 14 species accounting for $87.8 \%$ of all amphipods taken. The Ampeliscidae rank second (4 species and $4.8 \%$ ), just before the Lysianassidae ( 9 species and $4.6 \%$ ). With the 4 next-most important families, the Haustoriidae, Calliopiidae, Podoceridae and Eusiridae, the total relative abundance of these 7 families exceeds $99 \%$ of the amphipod community.

To assess the structure of the endobenthic amphipod component of the community, we used Ledoyer's (1975) data, based on 26 dredge samples taken mainly in 1969 from the cold mud bottoms where Stations $112 \mathrm{M}$ and $112 \mathrm{~N}$ are located (Table 1). Ledoyer found only 29 species, all but 1 of which occur in our supra- benthic samplings. His findings contrast sharply with ours: benthic samples were dominated by lysianassids, with Paratryphosites abyssi accounting for over $53 \%$ of all amphipods. Ampeliscids, haustoriids, melitids and isaeids were also more abundant than oedicerotids, which ranked only sixth in endobenthic samples (Table 1).

On the average, twice as many species per sample were caught in the lower net $(\overline{\mathrm{x}}=28.5 \pm 4.4, \mathrm{n}=26)$ as in the upper net $(\overline{\mathrm{x}}=14.5 \pm 2.3, \mathrm{n}=23)$, whereas the shrimp net caught still fewer $(\bar{x}=8.3 \pm 4.5$, $n=61$ ), about $29 \%$ of the lower net fauna. Fourteen species occurred in $100 \%$ of the lower net samples, and all except Bathymedon obtusifrons were present but occurred less frequently in the upper and shrimp nets (Table 3 ). At the 3 sampling levels, these 14 species represent more than $95 \%$ of all individuals taken. Among them are 8 Oedicerotidae, 3 Lysianassidae, 1 Ampeliscidae, 1 Haustoriidae and 1 Calliopiidae.

Table 1. Relative abundance (\% $\mathrm{N}$ ) and number of species (s) of gammaridean families in or above offshore mud in Baie des Chaleurs from May to October excluding 2-3 September

\begin{tabular}{|c|c|c|c|c|c|c|c|c|c|c|c|}
\hline \multirow[t]{2}{*}{ Family } & \multirow[t]{2}{*}{$\begin{array}{l}\text { Family } \\
\text { code }\end{array}$} & \multicolumn{2}{|c|}{$\begin{array}{l}\text { Dredges }^{a} \\
1968-69\end{array}$} & \multicolumn{2}{|c|}{$\begin{array}{l}\text { Lower net } \\
1969\end{array}$} & \multicolumn{2}{|c|}{$\begin{array}{l}\text { Upper net } \\
1969\end{array}$} & \multicolumn{2}{|c|}{$\begin{array}{l}\text { Shrimp net } \\
1961-62\end{array}$} & \multirow{2}{*}{$\begin{array}{c}\text { Three nets } \\
1961-62,69 \\
\% N^{b}\end{array}$} & \multirow{2}{*}{$\begin{array}{c}\text { Tota } \\
\mathrm{s}\end{array}$} \\
\hline & & $\% N$ & s & $\% \mathrm{~N}$ & $s$ & $\% \mathrm{~N}$ & s & $\% \mathrm{~N}$ & s & & \\
\hline Oedicerotidae & $\mathrm{OD}$ & 3.33 & 4 & 88.67 & 13 & 82.22 & 11 & 64.09 & 9 & 87.79 & 14 \\
\hline Ampeliscidae & AM & 18.48 & 4 & 4.02 & 4 & 9.56 & 2 & 9.11 & 1 & 4.78 & $5^{c}$ \\
\hline Lysianassidae & LY & 55.76 & 4 & 4.58 & 8 & 4.97 & 6 & 7.80 & 6 & 4.64 & 9 \\
\hline Haustoriidae & $\mathrm{HA}$ & 10.48 & 1 & 0.62 & 1 & 0.30 & 1 & 12.74 & 1 & 0.59 & 1 \\
\hline Calliopiidae & $\mathrm{CA}$ & 0 & 0 & 0.41 & 3 & 0.75 & 2 & 0.24 & 2 & 0.45 & 4 \\
\hline Podoceridae & $\mathrm{PO}$ & 0 & 0 & 0.49 & 3 & 0.15 & 3 & 0 & 0 & 0.45 & 3 \\
\hline Eusiridae & $\mathrm{EU}$ & 0.16 & 2 & 0.32 & 4 & 1.01 & 2 & 0.45 & 3 & 0.44 & 4 \\
\hline Argissidae & $\mathrm{AR}$ & 0 & 0 & 0.19 & 1 & 0.33 & 1 & 0 & 0 & 0.21 & 1 \\
\hline Stenothoidae & $\mathrm{SN}$ & 0.24 & 1 & 0.14 & 7 & 0.15 & 4 & 0 & 0 & 0.14 & 8 \\
\hline Synopiidae & SY & 0 & 0 & 0.10 & 2 & 0.19 & 1 & 0.97 & 2 & 0.11 & 2 \\
\hline Lilljeborgiidae & LI & 0.24 & 1 & 0.11 & 1 & 0.07 & 1 & 0 & 0 & 0.10 & 1 \\
\hline Ischyroceridae & IC & 0 & 0 & 0.07 & 3 & 0 & 0 & 0 & 0 & 0.06 & 3 \\
\hline Isaeidae & IA & 4.52 & 3 & 0.07 & 3 & 0 & 0 & $<0.01$ & 1 & 0.06 & 3 \\
\hline Melitidae & ML & 4.68 & 4 & 0.05 & 3 & 0.03 & 2 & 4.44 & 3 & 0.05 & 3 \\
\hline Stegocephalidae & $\mathrm{SG}$ & 0 & 0 & 0.05 & 1 & 0.03 & 1 & 0 & 0 & 0.05 & 1 \\
\hline Corophiidae & $\mathrm{CO}$ & 1.56 & 2 & 0.03 & 2 & 0.05 & 1 & 0 & 0 & 0.04 & 2 \\
\hline Pleustidae & PL & 0 & 0 & 0.02 & 3 & 0 & 0 & 0 & 0 & 0.02 & 3 \\
\hline Pardaliscidae & $\mathrm{PD}$ & 0 & 0 & 0.01 & 1 & 0.03 & 1 & 0.10 & 1 & 0.01 & 1 \\
\hline Phoxocephalidae & PX & 0.32 & 2 & 0.01 & 3 & 0 & 0 & 0 & 0 & 0.01 & 3 \\
\hline Melphidippidae & MP & 0 & 0 & 0.01 & 1 & 0 & 0 & 0.05 & 1 & 0.01 & 1 \\
\hline Astyridae & AS & 0 & 0 & 0.01 & 1 & 0 & 0 & 0 & 0 & 0.01 & 1 \\
\hline Lepechinellidae & LE & 0 & 0 & 0.01 & 1 & 0 & 0 & 0 & 0 & 0.01 & 1 \\
\hline Amphilochidae & $A P$ & 0 & 0 & 0.01 & 1 & 0 & 0 & 0 & 0 & 0.01 & 1 \\
\hline Acanthonotozomatidae & $\mathrm{AC}$ & 0.16 & 1 & 0.01 & 2 & 0 & 0 & 0 & 0 & $<0.01$ & 2 \\
\hline Epimeriidae & EP & 0 & 0 & $<0.01$ & 1 & 0 & 0 & 0 & 0 & $<0.01$ & 1 \\
\hline Number of individuals (N) & & 1151 & - & 37281 & - & 4359 & - & 3807 & - & 45447 & - \\
\hline Number of species (s) & & - & 29 & - & 72 & - & 39 & - & 30 & - & 77 \\
\hline \multicolumn{12}{|c|}{$\begin{array}{l}{ }^{b} \text { Mean relative abundance of family in the } 3 \text { suprabenthic nets, weighted for total density in each net } \\
\text { c One species caught only in dredges }\end{array}$} \\
\hline
\end{tabular}


Table 2. Frequency ( $\%$ of $N$ ) of Amphipoda Gammaridea in the plankton of Baie des Chaleurs in 1969 (Poirier 1970). Station locations given in Fig. 1. Horizontal tows at depths of 25, 50, 75, 100 (or 125), and $175 \mathrm{~m}$, depending on bottom depth, with $0.5 \mathrm{~m}$ standard net $(0.5 \mathrm{~mm}$ mesh) monitored with a Furuno depth recorder

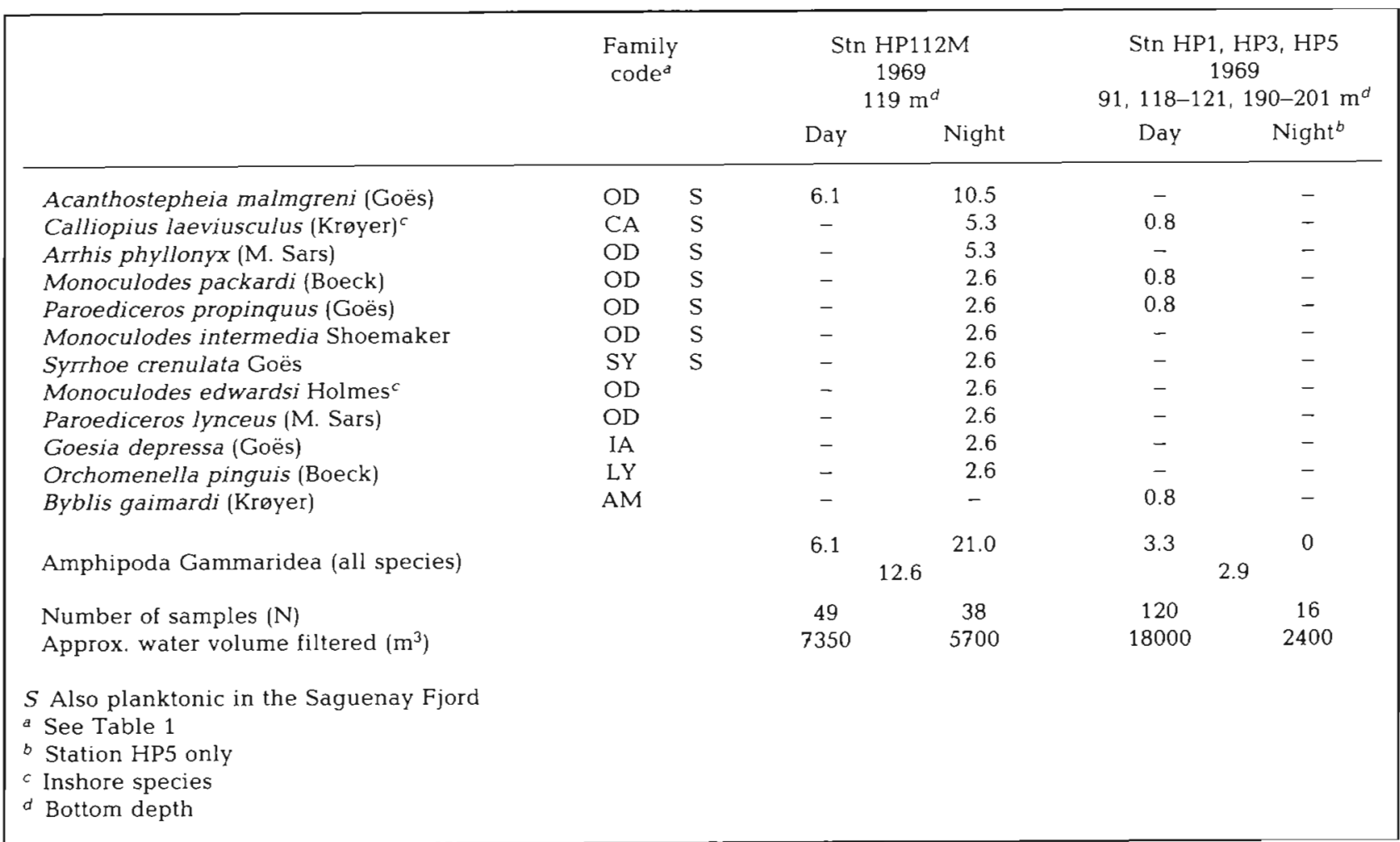

Table 3. Mean day-and-night density of the 14 dominant (100\% occurrence in the lower net) gammaridean species at the 3 suprabenthic levels sampled at Stations $112 \mathrm{M}$ and $112 \mathrm{~N}$, excluding $2-3$ September 1969 . Enclosed values indicate occurrence in more than $90 \%$ of the samples

\begin{tabular}{|c|c|c|c|c|}
\hline \multirow[t]{2}{*}{ Species } & \multirow[t]{2}{*}{ Family code } & \multicolumn{3}{|c|}{ Mean density (indiv $100 \mathrm{~m}^{-3}$ ) } \\
\hline & & Lower net 1969 & Upper net 1969 & Shrimp net $1961-62$ \\
\hline Monoculodes packardi & $O D$ & 283.2 & 23.7 & 0.1 \\
\hline Aceroides latipes & OD & 253.6 & 12.8 & 0.1 \\
\hline Arrhis phyllonyx & $\mathrm{OD}$ & 157.6 & 7.4 & $<0.1$ \\
\hline Acanthostepheia malmgreni & OD & 102.4 & 65.0 & 1.1 \\
\hline Bathymedon obtusifrons & $\mathrm{OD}$ & 100.6 & 20.3 & 0 \\
\hline Paroediceros propinquus & OD & 84.3 & 10.7 & 0.1 \\
\hline Byblis gainardi & AM & 45.3 & 16.7 & 0.2 \\
\hline Anonyx makatovi & LY & 30.4 & 3.1 & 0.1 \\
\hline Monoculodes longirostris & $\mathrm{OD}$ & 25.1 & 0.5 & $<0.1$ \\
\hline Hippomedon propinquus & LY & 12.6 & 3.6 & $<0.1$ \\
\hline Orchomenella pinguis & LY & 8.3 & 1.9 & $<0.1$ \\
\hline Pontoporeia femorata & $\mathrm{HA}$ & 7.1 & 0.5 & 0.2 \\
\hline Monoculodes intermedia & $O D$ & 5.5 & 0.7 & $<0.1$ \\
\hline Halirages fulvocinctus & $\mathrm{CA}$ & 4.4 & 1.2 & $<0.1$ \\
\hline Total for 14 dominant species & & 1120.4 & 168.1 & 2.1 \\
\hline Total for all 77 species & & 1150.6 & 174.9 & 2.2 \\
\hline
\end{tabular}




\section{Common suprabenthic species}

Because of the fairly large number of samples available from each depth level and yearly series, meaningful quantitative comparisons among the different types of samples (plankton nets, shrimp net, suprabenthic nets on the sled, dredge and cod stomach contents) can be made using frequencies ( $\%$ occurrence), relative abundance, or ranks of the species (Tables $4 \& 5$ ). Such parameters minimize yearly differences, which mainly affect absolute abundance. Above the shrimp net, one may expect great dispersion and poor sampling of rare or active swimmers which should occur at very low frequencies in planktonic surveys. We have used unpublished data from intensive surveys by Poirier (1970) in 1969. Data from the coarse-mesh and faster shrimp net are expected to be biased against small species, and for the more active swimmers, and so are cod stomach contents. The 2 suprabenthic nets on the sled can be compared directly to each other through the swimming index, $\mathrm{K}$; their data are meaningful only for migratory activity at distances up to some $2 \mathrm{~m}$ above the bottom, but can provide good information on even less common or smaller species. Finally, the dredge samplings of Ledoyer (1975) which are used to infer endobenthic representation of the species covered very small surfaces of bottom and must have been biased against the sparser, larger or more active species with a swimming escape response (Huberdeau \& Brunel 1982).

For the purposes of the present ecological study, species are considered as commonly suprabenthic when their frequency is higher than $12 \%$ in at least 1 of the 3 suprabenthic nets providing the core of our own data, or when they are present at more than 2 suprabenthic levels, including cod stomachs. In our own data and for the similar suprabenthic populations of gammarideans studied much more intensively in 1970-71 by Besner (1976) in the Lower St. Lawrence Estuary, this proportion of $12 \%$ has been found to constitute a natural limit below which a much larger volume of water must be filtered to provide a representation of the rarer species which is meaningful for ecological analysis. The 51 species satisfying this criterion are listed, ranked and separated into 7 groups (Table 5), distinguished mainly by quantitative criteria (Table 4) measuring different combinations of the 3 properties of vertical migrations outlined by Brunel (1972): (a) Intensity refers to the proportion of the core population taking part in vertical migrations; (b) extent or amplitude is the maximum distance away from the bottom reached by the most migratory component of the population; (c) regularity describes the temporal recurrence or rhythmic character of migratory

Table 4. Criteria used to define seven suprabenthic groups of gammaridean species captured with the Macer-GIROQ sled and the upper shrimp net at Stations $112 \mathrm{M}$ and $112 \mathrm{~N}$ and in the 26 endobenthic samples of Ledoyer (1975) in the same community

\begin{tabular}{|c|c|c|c|c|c|c|c|c|}
\hline \multirow{3}{*}{$\begin{array}{l}\text { Group } \\
\text { no. }\end{array}$} & \multirow{3}{*}{$\begin{array}{l}\text { Group } \\
\text { name }\end{array}$} & \multicolumn{4}{|c|}{ Suprabenthic frequency $(\%)$} & \multirow{3}{*}{$\begin{array}{c}\% \\
\text { Species } \\
\text { occur- } \\
\text { ing in } \\
\text { plankton }\end{array}$} & \multirow{2}{*}{\multicolumn{2}{|c|}{$\begin{array}{c}\text { Endobenthic } \\
\text { relative } \\
\text { abundance }(\%) \\
1968-69\end{array}$}} \\
\hline & & \multirow[t]{2}{*}{$\begin{array}{l}\text { Swimming } \\
\text { index } \\
\overline{\mathrm{K}}\end{array}$} & \multirow[t]{2}{*}{$\begin{array}{c}\text { Lower } \\
\text { net } \\
1969\end{array}$} & \multirow[t]{2}{*}{$\begin{array}{c}\text { Upper } \\
\text { net } \\
1969\end{array}$} & \multirow[t]{2}{*}{$\begin{array}{l}\text { Shrimp } \\
\text { net } \\
1961-62\end{array}$} & & & \\
\hline & & & & & & & mean & range \\
\hline 1 & $\begin{array}{l}\text { Uppermost } \\
\text { (poorly sampled) } \\
\text { suprabenthos }\end{array}$ & $\begin{array}{l}\text { not } \\
\text { signifi- } \\
\text { cant }\end{array}$ & $0-10$ & $0-10$ & $0-10$ & 67 & 0 & 0 \\
\hline 2 & $\begin{array}{l}\text { Upper } \\
\text { suprabenthos }\end{array}$ & $0.25-0.43$ & $40-100$ & $25-100$ & $5-95$ & 100 & 0.05 & $0-0.4$ \\
\hline 3 & $\begin{array}{l}\text { Transitional } \\
\text { suprabenthos }\end{array}$ & $0.02-0.25$ & $75-100$ & $25-100$ & $5-95$ & 58 & 0.35 & $0-2.0$ \\
\hline 4 & $\begin{array}{l}\text { Major } \\
\text { suprabenthic } \\
\text { swarmers }\end{array}$ & $0.07-0.44$ & $5-100$ & $5-95$ & $35-60$ & 33 & 25.7 & $10-60$ \\
\hline 5 & $\begin{array}{l}\text { Swift } \\
\text { (poorly sampled) } \\
\text { transitional suprabenthos }\end{array}$ & $\begin{array}{l}\text { not } \\
\text { signifi- } \\
\text { cant }\end{array}$ & $0-40$ & $0-5$ & $5-40$ & 50 & 0.15 & $0-0.5$ \\
\hline 6 & $\begin{array}{l}\text { Lower } \\
\text { suprabenthos }\end{array}$ & $0.02-0.27$ & $25-75$ & $5-25$ & $0-10$ & 30 & 0.22 & $0-2.0$ \\
\hline 7 & $\begin{array}{l}\text { Lowermost } \\
\text { suprabenthos }\end{array}$ & 0 & $5-95$ & $0-5$ & $0-5$ & 8 & 0.89 & $0-5.0$ \\
\hline
\end{tabular}




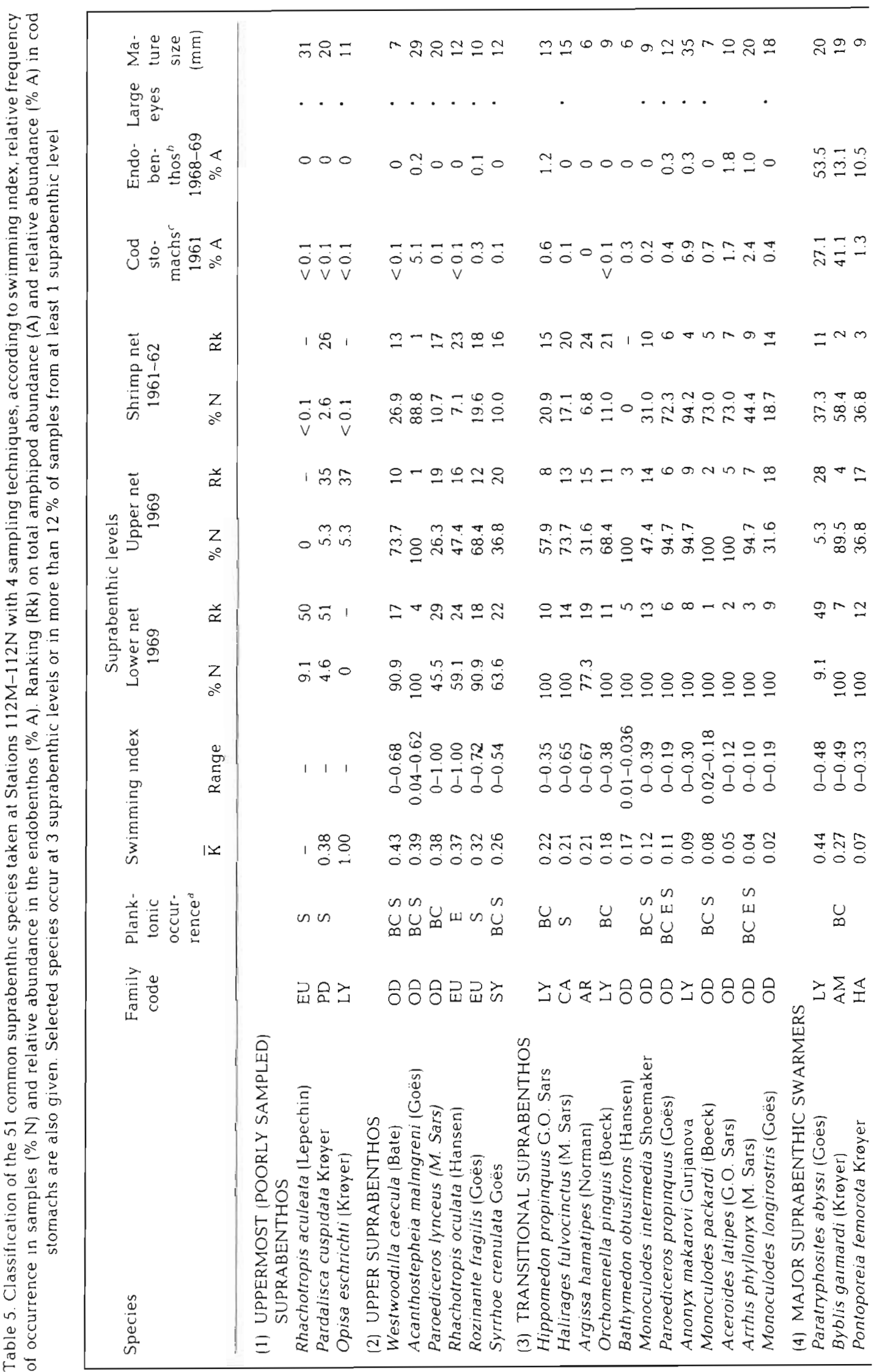




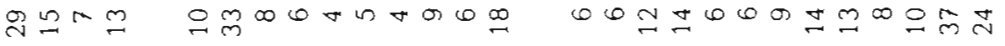

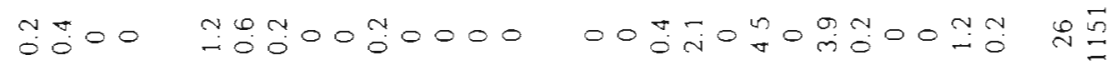

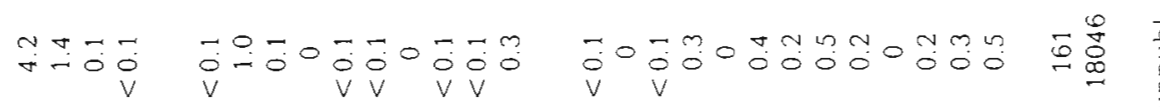

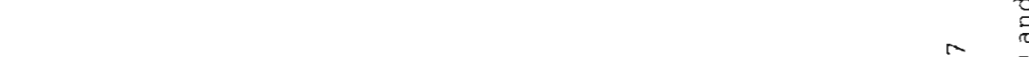

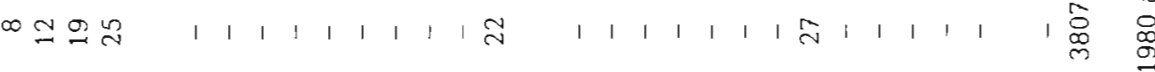

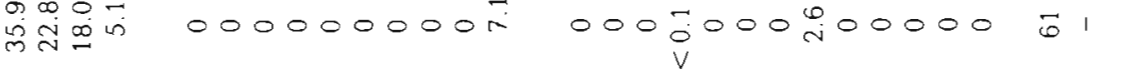

| 1 1 1

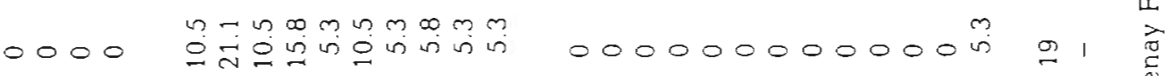

m।

$\forall \overrightarrow{0}+60$ m-

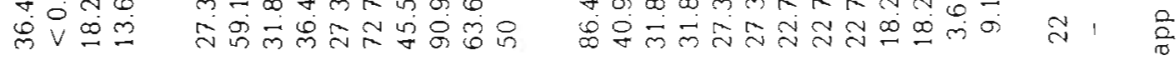

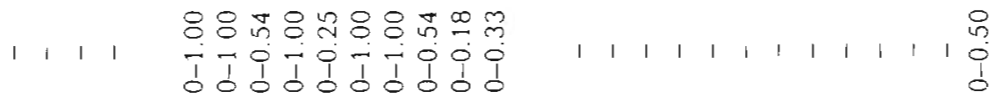

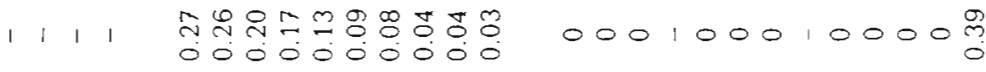

inen in an in in

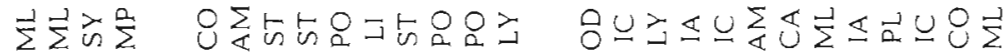

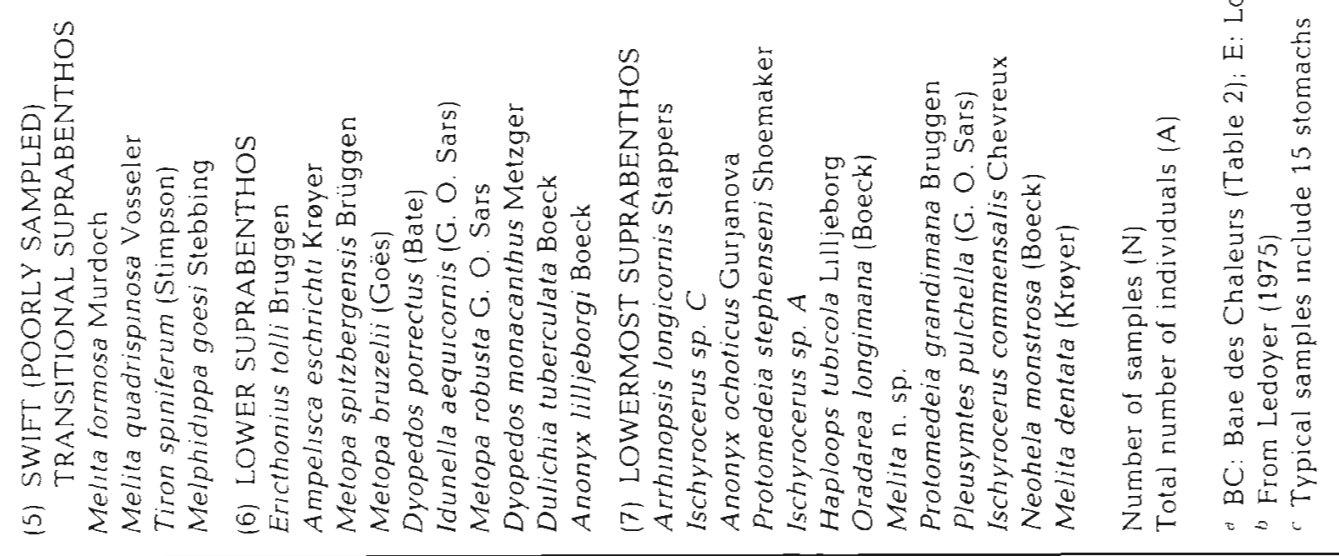


activity, seasonal and daily rhythms being the most significant in the populations under study.

In forming the 7 groups of suprabenthic swimming activity, we have relied mainly on our own measurements (Tables $4 \& 5$ ), supplemented occasionally by outside evidence (see 'Discussion'). The groups are listed in their presumed order of decreasing swimming activity as we interpret it in the discussion. The eighth mixed group of 31 or more rare species excluded from further consideration here may include both autochthonous and allochtonous species. The former may be non-swimmers fairly frequent in the endobenthos, or genuine fugitive swimmers belonging to any of the other 7 groups. Most allochtonous species are probably good swimmers straying from their centers of abundance in neighboring communities, such as Calliopius laeviusculus and Monoculodes edwardsi, 2 good swimmers (Whiteley 1948, Steele \& Steele 1973) from inshore communities which were caught in the plankton (Table 2) or in the suprabenthos over our offshore mud community.

\section{DISCUSSION}

Daily vertical migrations and swimming activity have been thoroughly documented for many zooplanktonic species. Although similar light-triggered movements are known in the suprabenthos, they are much more poorly known, especially in their quantitative and comparative aspects at the community level. In theory, one may expect a complete continuum of migratory amplitude and intensity ranging from fully planktonic forms approaching the bottom during the day, through increasingly bottom-dependent species making shorter or fewer swimming excursions upward, down to endobenthic species swimming or crawling out of their burrows or tubes for very short daily periods. In the absence of direct, long-term in situ observations or laboratory experiments, demonstrations of the natural suprabenthic character of forms caught swimming off the bottom must be indirect. Of greatest importance are the relative abundances of the different species at various distances from the bottom, and comparisons of such distributions between different communities and ecosystems. They can be supplemented with evidence on feeding habits, morphological adaptations for swimming, and catchability by visually preying fish.

We examine below first the evidence for such a planktonic-suprabenthic-epibenthic gradient in the amplitude, intensity and regularity of vertical swimming movements. Attention is then successively focused on the structure of the suprabenthic community as a whole and on possible factors of suprabenthic swimming, including its functional significance.
Gammaridean groups in the suprabenthic continuum

Uppermost suprabenthos consists of active far-ranging and apparently dispersed species with a strong swimming capacity often combined with large size and good sensory, especially visual, powers. The families Eusiridae and Pardaliscidae are very commonly represented by several species in plankton (Birstein \& Vinogradov 1964 and earlier papers, Brunel et al. 1980). Both Rhachotropis aculeata and Pardalisca cuspidata occur at comparable frequencies well above the bottom in the Saguenay Fjord: the former was taken in $8.6 \%$ of 394 plankton samples over the muddy upstream slopes (Brunel et al. 1980), the latter occurred in $3.4 \%$ of 233 samples over the downstream trough (own unpubl. data). Because of their mobility and large size, these species are more frequently caught by faster and coarser-meshed trawls, either at suprabenthic (Brunel 1956) or pelagic (Brunel et al. 1980) levels, or by visually preying codfish (Brunel 1956, Table 5). Our sampling of these dispersed and elusive forms is therefore unsatisfactory.

The small Opisa eschrichti marginally satisfies our arbitrary criteria for consideration as a 'major suprabenthic species', but it occurs at too low frequencies for conclusive interpretation. Outside evidence rather points to its less extensive vertical movements and genuine overall scarcity: it was never found in plankton, but did occur sparsely in both suprabenthic nets in the Lower Saint Lawrence Estuary (Besner 1976) and in beam trawl samples from Baie des Chaleurs (Brunel 1956).

Upper and transitional suprabenthos probably contains the most typically suprabenthic species of the gammaridean fauna: 7 of their 18 species are also present among Besner's (1976) most important suprabenthic swimmers (his groups 1-2). Most species in both groups have large eyes and are represented in plankton surveys in Baie des Chaleurs, the Saguenay Fjord and the Lower Saint Lawrence Estuary (Table 5).

Upper suprabenthos includes species which swim very intensively and regularly off the bottom. They are occasionally found in greater abundance in the upper net than in the lower net $(\mathrm{K}>0.5)$, and are very scarce in the endobenthos. Only Westwoodilla caecula is known to be abundant in endobenthic samples in some areas (Barrie et al. 1980 unpubl.). Except for Acanthostepheia malmgreni, they are not very abundant, as shown by their ranks (Table 5). The large A. malmgreni was quite common in the plankton of the Saguenay Fjord, occurring in up to $15.6 \%$ of 275 tows as far as $100 \mathrm{~m}$ off the bottom in the central mud basin (Brunel et al. 1980). In Baie des Chaleurs, it was easily seen and caught by cod (Table 5).

Transitional suprabenthos comprises all but 2 of the 
10 dominant members of the suprabenthic community (Table 3), and it can be seen from their ranks (Table 5) that 6 of these species maintain much of their dominance at the 3 suprabenthic levels. They are: Monoculodes packardi, Aceroides latipes, Arrhis phyllonyx, Bathymedon obtusifrons, Paroediceros propinquus and Anonyx makarovi. The other less abundant species tend to have higher swimming indices, but it is generally uncertain whether this is due to their slightly more extensive migratory movements or to the suboptimal conditions of the bottom community in the Bay.

One might suspect that the 3 species with the lowest frequencies in the coarse-mesh shrimp net-Bathymedon obtusifrons, Argissa hamatipes and Orchomenella pinguis - have been undersampled because of their small size ( 6 to $9 \mathrm{~mm}$ at maturity). However, $A$. hamatipes is also the least frequent species in Group 3 at all levels, and diving observations (Sainte-Marie unpubl.) at night show that $O$. pinguis apparently does not swim far out of the sediment at high tide in Baie des Rochers (Middle Saint Lawrence Estuary), where it is very abundant; both species might therefore belong to lower suprabenthos. Indeed, Aceroides latipes, Monoculodes packardi and Westwoodilla caecula were very or fairly frequent in the shrimp net despite their very small size (Table 5). Annual differences of abundance between 1961-62 and 1969 cannot yet be ruled out to explain such discrepancies.

Major benthic swarmers show a bimodal vertical distribution, being massively dominant in the endobenthos and at the same time fairly frequent and increasingly abundant (as indicated by their rank) at upper sampling levels (Table 5); they vary from uncommon (Paratryphosites abyssi) to frequent (Byblis gaimardi and Pontoporeia femorata) in the lower net. All 3 species give evidence of high nocturnal aggregation, which is known (Brunel 1968, 1979) to be markedly seasonal, in 1961-62: $P$. abyssi swarms massively in early May, earlier than the start of our 1969 sampling program, B. gaimardi does so in July-August and $P$. femorata swarms in October. Mature males are massively dominant in these swarms, demonstrating the breeding character of such synchronous swimming activity. In these periods, swarmers represent a valuable food source for cod, which then preys heavily and almost exclusively on them (Table 5); $P$. femorata escapes from this heavy predation because in October cod is passively drifting southward in midwater at night (Brunel 1972).

Swift transitional suprabenthos, characterized by another kind of bimodal vertical distribution (Tables 4 \& 5), is interpreted as showing biased sampling because catches of its species probably reflect their behavioral reactions toward our sampling devices: an escape swimming response from a resting benthic posture into the lower net, and a much more effective avoidance, by the naturally swimming individuals of the population, of the slow upper net than of the faster shrimp net or of the foraging cod. Moreover, the lower net caught smaller, and therefore weaker-swimming, individuals of Melita than the shrimp net and cod (Table 5). Enequist (1949) reports that most Melitidae are nestlers or domicolous with varying swimming behavior in the aquarium. Enequist (1949) and Atkinson et al. (1982) have observed the burrowing, domicolous behavior of Maera loveni (Bruzelius), a large Melitidae which is too scarce in our material for study. Ceradocus torelli (Goës) is another large (up to $58 \mathrm{~mm}$ ) and actively swimming Melitidae which cod could catch better than our nets. Enequist (1949) also observed the peculiar epibenthic resting and filtering behavior of Melphidippella macra, an otherwise active swimmer presumably similar to our Melphidippa goesi; the latter species occurred in up to $27 \%$ of many plankton samples taken in the downstream rocky regions of the Saguenay Fjord (Brunel et al. 1980).

Lower suprabenthos contains species which are obviously less frequent and abundant at all 3 suprabenthic levels and in the plankton than those of the 5 previous groups (Tables $4 \& 5$ ). Although their swimming indices span a range comparable to those of transitional suprabenthos, their virtual absence from the shrimp net suggests either a smaller migratory amplitude or intensity, or a genuine overall scarcity in the community. If their migrations were less extensive than those of transitional suprabenthos, this should be apparent in their increased endobenthic abundance; but they are in fact relatively less abundant in the sediments (Tables $4 \& 5$ ). On the other hand, they may be undersampled by the coarse shrimp net and by the cod, both because of their small size (except Ampelisca eschrichti) and of their general scarcity in the community. The group includes all 3 species of Podoceridae, which climb on detritus rods (Laubitz 1979) and may escape into the oncoming nets when disturbed, and 3 Stenothoidae, most of which are specialized and presumably dispersed and sparse commensals or specialized predators (Barnard 1969, Bousfield 1973, Besner 1976). Idunella aequicomis is dominant in the endobenthos and occurs irregularly up to the upper net level in the Lower Saint Lawrence Estuary (Besner 1976). Ericthonius tolli and Ampelisca eschrichti are normally tube-dwelling (Enequist 1949) but can obviously swim up to the upper net level and even in the plankton.

Lowermost suprabenthos clearly does not swim much farther upward than the lower net level, and does move down into the sediment, where it is on the average four times more abundant than the previous group. No less than 6 species in this group are tube- 
dwellers (3 Ischyrocerus, 2 Protomedeia and the common Haploops tubicola), one is a known tunnel-digger (Neohela monstrosa) and most of the others are probably nestlers or burrowers (Enequist 1949).

\section{Structure of the suprabenthic gammaridean populations}

There is little doubt that significant numbers of several species of gammaridean amphipods swim naturally and regularly at a short distance from the muddy bottom of the outer shelf in the Gulf of Saint Lawrence. In Baie des Chaleurs, among the 82 species taken in the suprabenthic layer, 30 ranged to at least $3.7 \mathrm{~m}$ above the bottom, and 13 were occasionally taken in the plankton. Most of these species are known to depend, during much of their life, on the bottom or on the near-bottom layer for food or shelter, as shown by such aquarium studies as that of Enequist (1949).

Cold-water populations of gammarideans over deep mud in Baie des Chaleurs contained 51 species considered as significant in the suprabenthos. This is nearly twice as many as the 29 species recorded by Ledoyer (1975) in the endobenthos. Since this is evidently due to sampling size ( 4 times as many samples and 40 times as many individuals in suprabenthic samples, as shown in Table 5), family representation is a better indicator of structural differences between those 2 strata of the bottom community. Dominance by the Oedicerotidae at surpabenthic levels was overwhelming ( $88 \%$ of the 45447 gammarideans), whereas that family accounted for a mere $3 \%$ of all amphipods in Ledoyer's (1975) dredgings (Table 1). Endobenthic dominance was due to the burrowing lysianassid Paratryphosites abyssi, the tube-building ampeliscids Byblis gaimardi and Haploops tubicola, and the burrowing haustoriid Pontoporeia femorata, which altogether accounted for $82 \%$ of the 1151 gammarideans dredged by Ledoyer (1975). A similarly sharp difference in gammaridean family dominance between the endoand suprabenthos exists in the Lower Saint Lawrence Estuary (Besner 1976), although the Oedicerotidae in that ecosystem represent only 13 to $24 \%$ of suprabenthic gammaridean populations.

The communities in both ecosystems have dominant suprabenthic species which, although they belong to different families, have large eyes, keels and strongly prehensile gnathopods: Acanthostepheia malmgreni, an Oedicerotidae in the present classification, is the most abundant at the upper and shrimp net levels (Tables 3 \& 5) on the Baie des Chaleurs shelf (depth $120 \mathrm{~m}$ ), whereas the eusirid Rhachotropis oculata is still more dominant at a comparable depth at the upper net level in the Lower Saint Lawrence Estuary (Besner 1976). Huberdeau \& Brunel (1982) have shown domi- nance of $R$. oculata in the infralittoral (18 $\mathrm{m}$ ) suprabenthos and of the eyeless $R$. distincta (Holmes) at bathyal depths $(350 \mathrm{~m})$ in the Lower Saint Lawrence Estuary, and Brunel et al. (1980) report planktonic dominance of $A$. malmgreni and $R$. aculeata over the muddy upstream depths of the Saguenay Fjord. The convergent morphological characters of all these species are probable adaptations for efficient directional swimming and predation on mobile prey of smaller size (see below). Dominance of characteristic predatory swimmers thus appears to be a distinctive property of the suprabenthic layer of cold-water and soft-bottom communities.

\section{Factors of suprabenthic swimming}

In view of the diversity of suprabenthic swimming patterns which is suggested in the present paper and in forthcoming analyses of our data, it is unlikely that a single factor could account for such activity. These factors can be either broadly adaptive functions, which are our main concern here, or more proximate triggering or entraining mechanisms. The latter include the classic photokinetic responses, which have been well studied experimentally in suprabenthic peracarids by Macquart-Moulin $(1972,1977)$, and the sinking-diffusion hydrodynamic model applied by Sibert (1981) to the smaller harpacticoid copepods. Different adaptive functions may be attributed to the permanent swimming activity of upper or transitional suprabenthos, to the more seasonal migrations of major suprabenthic swarmers, and to the daily rhythms of most swimmers, culminating into the short-term nocturnal emergence of burrowing or domicolous forms into the suprabenthic layer.

It is almost a truism to state that permanently swimming forms in the plankton or in the suprabenthic layer have evolved an adaptive dependence on their pelagic environment. Morphological adaptations for stable and directional swimming, such as keels in the Eusiridae, Synopiidae, Pardaliscidae and Acanthostepheia malmgreni, and for visual perception in the same forms plus many Lysianassidae, and the actual vertical distribution of these forms (present paper), provide indirect but nonetheless convincing evidence of their probable foraging activity in either of these environments. Critical tests of their planktonic or suprabenthic adaptation, however, should rest on demonstration of the extent of their dependence on factors of the bottom, such as protective refuges, resting sites, or benthic prey, or of the bottom-related suprabenthic layer, such as turbulence in the benthic boundary layer, resuspended seston of the nepheloid layer, suprabenthic prey, or demersal accumulation of downward-migrating or advected zooplanktonic prey 
(truly 'demersal zooplankton'). Since swimming ability enables these animals to overcome both turbulence and moving prey, and to explore larger water volumes or bottom surfaces, large size and correlated swimming strength have certainly been valuable assets in their evolutionary adaptation for large-scale and long-term suprabenthic foraging. We suggest that these large forms may forage either for pelagic prey within the suprabenthic layer, or roam through this layer in search of epibenthic prey or carrion lying on the seabed.

The genus Rhachotropis has been assumed, from gut contents (Enequist 1949) or presumably morphological evidence (Vader and Kane 1968), to include active predatory species, and analyses of gut contents are now confirming that $R$. oculata and Acanthostepheia malmgreni consume both suprabenthic harpacticoid and presumably planktonic calanoid copepods (Desroches in prep.). Very little is known of the actual behavior of such copepod prey in the suprabenthic layer, although there is recent evidence that harpacticoids swim up into the suprabenthic layer of infralittoral tidal areas, such activity being tidal (Bell \& Sherman 1980) or arhythmic (Sibert 1981). In Baie des Rochers (Middle Saint Lawrence Estuary), SainteMarie (pers. obs.) has observed harpacticoids moving back and forth at about $1 \mathrm{~min}$ intervals between the suprabenthic layer and the bottom, under some $4 \mathrm{~m}$ of water at high tide. Our coarse-mesh nets provide no data on small suprabenthic harpacticoids offshore in Baie des Chaleurs, but both the upper and shrimp nets do catch large numbers of calanoids (Brunel 1979) whose descending migrations in daylight have presumably been stopped either by the suprabenthic community or by physical properties of the benthic boundary layer. Such suspension-feeding forms represent potential prey in the day, whereas the small suprabenthic peracarids (and probably harpacticoids and cyclopoids) moving up at night provide potential prey to the larger Crustacea which may be able to catch them in darkness.

Large-scale foraging for epibenthic food apparently characterizes some scavenging Lysianassidae. In the deep sea, they are able to locate carrion at distances which should depend on both their sensory and their searching skills (Jumars \& Gallagher 1982, Ingram \& Hessler 1983). A requirement of such foraging for patchy resources is the long-term exploratoy swimming of dispersed individuals which we observe in Anonyx makarovi (Table 3) and which Sainte-Marie (in prep.) finds in $A$. sarsi over infralittoral grounds. Thousands of $A$. makarovi have twice been found scavenging inside gill-netted codfishes at station $112 \mathrm{~N}$ in 1961-62 (own unpubl, data), and our results can therefore be interpreted as indications of its active roaming above the bottom in search of sensory clues of carrion (Brunel 1979, Sainte-Marie 1984), on which it will infrequently congregate massively. While foraging above the bottom, such large lysianassids may also incidentally prey on suprabenthic or pelagic prey (Smith \& Baldwin 1984, Sainte-Marie \& Lamarche in press). Because of its large size, white color, mobility and frequency, $A$. makarovi is highly visible and readily caught by cod (Table 5). The smooth, keel-less and well calcified cuticle of lysianassids is presumably valuable for their well known (own obs.) ability to burrow rapidly into flesh or almost any kind of substrate, an ability which should endow them with markedly opportunistic habits.

The suprabenthic swimming of such dominant forms as the detritus-feeding Oedicerotidae or the suspension-feeding Ampeliscidae is more difficult to explain in terms of foraging activity. Whereas the endo- or epibenthic feeding habits of species in these and other gammaridean families are fairly well known (e.g. Enequist 1949, Hudon 1983, McGrouther 1983), there exists no direct evidence that they can maintain their microphagous feeding in midwater, similar to that which is known for Mysidacea and Euphausiacea. Yet, on indirect evidence, pelagic suspension-feeding is presently the best hypothesis accounting for the abundance of the calliopiid Halirages fulvovinctus in the plankton of the lower Saguenay Fjord (Brunel et al. 1980). One should keep in mind here the ease with which many benthic forms, including for instance the Ampeliscidae (Mills 1967), can switch between detritus-feeding and suspension-feeding.

Breeding is the oldest and best-known factor of suprabenthic swimming (Fage 1933, Watkin 1939, 1941, Anger \& Valentin 1976, Porter \& Porter 1977, Brunel 1979) and here applies mainly to the major suprabenthic swarmers. The short-term, small-scale swimming of lower and some transitional suprabenthos probably calls for somewhat different kinds of interpretations. Porter \& Porter (1977) have suggested that reduced nocturnal predation by visual feeders (mainly fishes) may have provided selective value to that type of behavior, which may also allow these forms to migrate to new epibenthic settling or feeding sites. A daily downward return to small-scale patches of bottom resources would indeed tend to favor selection of improved resources, i.e. habitat quality, on a shortterm basis (e.g. Grant 1980). Such a strategy is available to the more weakly swimming small-size species or to the young of large-size species. Evidence for this type of strategy has been recently gathered for the tube-dwelling genus Microdeutopus by De Witt (1984).

Acknowledgements. We express our thanks to the Québec Department of Fisheries for providing ship time and financial 
assistance to P. Brunel, L. Poirier and D. Granger for collections at sea, and to G. Lamarche, A. Chevrier, J. LacelleGagnon, D. Maither and V. Neuhof, for their contribution to sorting and identifications. A. Chevrier also helped with the preliminary analysis of data. Scholarships (B. Sainte-Marie) and grants (P. Brunel and GIROQ) from the Natural Sciences and Engineering Research Council of Canada and Québec Ministry of Education supported this work. The National Museum of Natural Sciences, Ottawa, supported part of the extensive sorting and identification through a Summer Canada project.

\section{LITERATURE CITED}

Anger, K., Valentin, C. (1976). In situ studies on the diurnal activity pattern of Diastylis rathkei (Cumacea, Crustacea) and its importance for the 'hyperbenthos'. Helgoländer wiss. Meeresunters. 28: 138-144

Atkinson, R. J., Moore, P. G., Morgan, P. J. (1982). The burrows and burrowing behaviour of Maera loveni (Crustacea: Amphipoda). J. Zool., Lond. 198: 399-416

Barnard, J. L. (1969). Families and genera of marine gammaridean amphipods. U. S. Nat. Mus. Bull. 271: 1-535

Bell, S. S., Sherman, K. M. (1980). A field investigation of meiofaunal dispersal: tidal resuspension and implications. Mar. Ecol. Prog. Ser. 3: 245-249

Besner, M. (1976). Ecologie et échantillonnage des populations hyperbenthiques d' Amphipodes gammaridiens d'un écosystème circalittoral de l'estuaire maritime du SaintLaurent. M. Sc. thesis, Département de sciences biologiques, Université de Montréal, Montréal

Birstein, J. A., Vinogradov, M. E. (1964). Pelagicheskie gammaridy severnoi chasti Indiiskogo Okeana. Trudy Inst. Okeanol. 65: 152-196

Bossanyi, J. (1957). A preliminary survey of the small natant fauna in the vicinity of the sea floor off Blyth, Northumberland. J. Anim. Ecol. 26: 353-368

Bousfield, E. L. (1973). Shallow-water gammaridean amphipods of New England. Cornell University Press, Ithaca

Brunel, P. (1956). The bathymetric distribution of the benthic Amphipoda (Crustacea, Malacostraca) of Baie des Chaleurs, Gulf of St. Lawrence, and its bearing on zoogeography. M. Sc. thesis, Department of Zoology, University of Toronto, Toronto

Brunel, P. (1968). The vertical migrations of cod in the southwestern Gulf of St. Lawrence, with special reference to feeding habits and prey distribution. Ph. D. thesis, Marine Sciences Centre, McGill University, Montréal

Brunel, P. (1972). The Gaspé cod ecosystem in the Gulf of St. Lawrence. III. The daily and seasonal vertical migrations of cod (Gadus morhua) in 1960-62. Naturaliste can. 99: 287-357

Brunel, P. (1979). Seasonal changes of daily vertical migrations in a suprabenthic cold-layer shelf community over mud in the Gulf of St. Lawrence. In: Naylor, E., Hartnoll, R. G. (ed.) Cyclic phenomena in marine plants and animals. Pergamon Press, New York, p. 383-390

Brunel, P., Besner, M., Messier, D., Poirier, L., Granger, D., Weinstein, M. (1978). Le traîneau suprabenthique MacerGIROQ: appareil amélioré pour l'échantillonnage quantitatif étagé de la petite faune nageuse au voisínage du fond. Int. Revue ges. Hydrobiol. 63: 815-829

Brunel, P., de Ladurantaye, R., Lacroix, G. (1980). Suprabenthic gammaridean Amphipoda (Crustacea) in the plank- ton of the Saguenay Fjord, Québec. In: Freeland, H. J., Farmer, D. M., Levings, C. D. (ed.) Fjord oceanography Plenum Publishing Corp., New York, p. 609-613

Cornet, M., Lissalde, J.-P., Bochet, J.-M., Sorbe, J.-C., Amoureux, L. (1983). Données qualitatives sur le benthos et le suprabenthos d'un transect du plateau continental Sud-Gascogne. Cah. biol. mar. 24: 69-84

De Witt, T. H. (1984). The ecology and behavior of colonization and emigration of the tubicolous amphipod, Microdeutopus gryllotalpa. Ph. D. thesis, State Univ. N.Y., Stony Brook

Enequist, P. (1949). Studies on the soft-bottorn amphipods of the Skagerak. Zool. Bidr. Uppsala 28: 297-492

Fage, L. (1933). Pêches planctoniques à la lumière effectuées à Banyuls-sur-Mer et à Concarneau. III. Crustacés. Archs Zool. exp. gén. 76: 104-248

Grant, J. (1980). A flume study of drift in marine infaunal amphipods (Haustoriidae). Mar Biol. 56: 79-84

Hesthagen, I. H. (1973). Diurnal and seasonal variations in the near-bottom fauna - the hyperbenthos - in one of the deeper channels of the Kieler Bucht (Western Baltic). Kieler Meeresforsch. 29: 116-140

Hesthagen, I. H., Gjermundsen, B. (1978). The replicability of sampling the hyperbenthic region by means of Beyer's $50 \mathrm{~cm}$ epibenthic closing net. Meeresforsch. Rep. mar. Res. 26: 1-10

Hobson, E. S., Chess, J. R. (1976). Trophic interactions among fishes and zooplankters near shore at Santa Catalina Island, California. Fish. Bull. U. S. 74: 567-598

Huberdeau, L., Brunel, P. (1982). Efficacité et sélectivité faunistique comparée de quatre appareils de prélèvements endo-, épi- et suprabenthiques sur deux types de fonds. Mar. Biol. 69: 331-343

Hudon, C. (1983). Selection of unicellular algae by the littoral amphipods Gammarus oceanicus and Calliopius laeviusculus (Crustacea). Mar. Biol. 78: 59-67

Ingram, C. L., Hessler, R. R. (1983). Distribution and behavior of scavenging amphipods from the central North Pacific. Deep Sea Res. 30: 683-706

Jansson, B.-O., Kallander, C. (1968). On the diurnal activity of some littoral peracarid crustaceans in the Baltic Sea. J. exp. mar. Biol. Ecol. 2: 24-36

Jumars, P. A., Gallagher, E. D. (1982). Deep-sea community structure: three plays on the benthic proscenium. In: Ernst, W. G., Morin, J. G. (ed.) The environment of the deep sea. Prentice-Hall Inc., Englewood Cliffs, p. 217-255

Laubitz, D. R. (1979). Phylogenetic relationships of the Podoceridae (Amphipoda, Gammaridea). Bull. Biol. Soc. Wash. 3: $144-152$

Ledoyer, M. (1975). Les peuplements benthiques circalittoraux de la baie des Chaleurs (golfe du Saint-Laurent). Trav. Pêch. Québec 42: 1-141

McGrouther, M. A. (1983). Comparison of feeding mechanisms in two intertidal gammarideans, Hyale rupicola (Haswell) and Paracalliope australis (Haswell) (Crustacea: Amphipoda). Aust. J. mar. Freshwat. Res. 34: $717-726$

Macquart-Moulin, C. (1972). Modifications des réactions photocinétiques des Péracarides de l'hyponeuston nocturne en fonction de l'importance de l'éclairement. Téthys 3: $897-920$

Macquart-Moulin, C. (1977). Le contrôle de l'émergence et des nages nocturnes chez les Péracarides des plages de la Méditerranée. Eurydice affinis Hansen (Isopoda), Gastrosaccus mediterraneus Bacescu, Gastrosaccus spinifer (Goës) (Mysidacea). J. exp. mar. Biol. Ecol. 27: 61-81

Mills, E. L. (1967). The biology of an ampeliscid amphipod 
crustacean sibling species pair. J. Fish. Res. Bd Can. 24: 305-355

Poirier, L. (1970). Pêches hyperbenthiques et planctoniques quantitatives dans la partie sud-ouest du golfe SaintLaurent: protocole et méthodes en 1969. Direction des Pêches, Ministère de l'Industrie et du Commerce, Québec, Service de biologie, Rapport annuel 1969: 45-51

Porter, J W., Porter, K. G. (1977). Quantitative sampling of demersal plankton migrating from different coral reef substrates. Limnol. Oceanogr. 22: 553-555

Robichaux, D. M., Cohen, A. C., Reaka, M. L., Allen, D. (1981). Experiments with zooplankton on coral reefs, or, will the real demersal plankton please come up. P.S. Z.N Mar. Ecol. 2: 77-94

Sainte-Marie, B. (1984). Morphological adaptations for carrion feeding in four species of littoral or circalittoral lysianassid amphipods. Can. J. Zool. 62: 1668-1674

Sainte-Marie, B., Brunel, P. (1983). Differences in life history and success between suprabenthic shelf populations of Arrhis phyllonyx (Amphipoda, Gammaridea) in two ecosystems of the Gulf of St. Lawrence. J. Crust. Biol. 3: 45-69

Sainte-Marie, B., Lamarche, G. (in press). The diets of six species of the carrion-feeding lysianassid amphipod genus Anonyx and their relation with morphology and swimming behaviour. Sarsia

Schafer, C. T. (1977). Distribution and depositional history of sediments in Baie des Chaleurs, Gulf of St. Lawrence. Can. J. Earth Sci. 14: 593-605

Schafer, C. T., Wagner, F. J. E. (1978). Foraminifera-mollusc associations in eastern Chaleur Bay. Can. J. Earth Sci. 15: 889-901

Sibert, J. R. (1981). Intertidal hyperbenthic populations in the Nanaimo Estuary. Mar. Biol. 64: 259-265

Smith, K. L. Jr., Baldwin, R. J. (1984). Vertical distribution of the necrophagous amphipod, Eurythenes gryllus, in the North Pacific: spatial and temporal variation. Deep Sea Res. 31: 1179-1196

Sorbe, J.-C. (1982). Observaciones preliminares del suprabenthos en un transecto batimétrico de la plataforma continental aquitana (suroeste de Francia). Oecologia aquat. 6: 9-17

Steele, D. H., Steele, V. J. (1973). Some aspects of the biology of Calliopius laeviusculus Krøyer (Crustacea, Amphipoda) in the northwestern Atlantic. Can. J. Zool. 51: 723-728

Tattersall, W. M. (1913). Clare Island survey. Amphipoda. Pt. 42. Proc. R. Ir. Acad. 31: 1-42

Thomas, M. L. H., Jelley, E. (1972). Benthos trapped leaving the bottom in Bideford River, Prince Edward Island. J. Fish. Res. Bd. Can. 29: 1234-1237

Vader, W., Kane, J. E. (1968). New hosts and distribution records of Thalasomyces marsupii Kane, an ellobiopsid parasite on amphipods. Sarsia 33: 13-20

Watkin, E. E. (1939). The pelagic phase in the life history of the amphipod genus Bathyporeia. J. mar. Biol. Ass. U.K 23: $467-481$

Watkin, E. E. (1941). Observations on the night tidal migrant Crustacea of Kames Bay. J. mar. Biol. Ass. U. K. 25: 81-96

Whiteley, G. C. (1948). The distribution of larger planktonic Crustacea on Georges Bank. Ecol. Monogr. 18: 233-264

This paper was submitted to the editor; it was accepted for printing on February 2, 1984 